\title{
Enhancing the Learning Process with Blended Learning
}

\author{
E. V. Ramkumar, R. Vani
}

\begin{abstract}
Learning is a wonderful and never ending process. Teaching plays a vital role in the process of learning. Teaching should never be considered as an occupation. It might be a Passion. A Passionate teacher always thinks about the effective tools which make his students' learning process easy and interesting. Blended Learning will be a wonderful tool for these passionate teachers. In this globalized world, blended learning tools and techniques attract the students and also make the learning process an interesting one. This paper clearly explicates about the effectiveness of blended learning in two environments.
\end{abstract}

Keywords - Blended learning, learning process, process, tools and techniques.

\section{INTRODUCTION}

In the field of e-learning Blended Learning has become a familiar one. In this globalised world, technological developments make a drastic change in the field of education. The digital era occupies the learning process and makes it simple with the assistance of internet. It results in the popularity of the blended learning.

Blended Learning is an approach which combines the traditional face to face classroom with the online resources and materials. This type of learning integrates digital tools, materials and techniques with the traditional place-based classroom methods. Blended learning needs the physical presence of the teacher and the student with the control over time, place, path or pace.

\section{TASK-BASED LEARNING}

Task-Based Learning (TBL), one of the most talked-about recent methods, can be traced back to the strong Communicative Approach, where teaching is done entirely through communicative tasks. Focusing on language use after a task has been completed is widely accepted as an aid to acquisition, and task repetition gives students the chance to practice new language.

\section{REVIEW OF LITERATURE}

Several studies have been made on analyzing the effects of blended learning in the teaching field. Some of them are given below.

Nuno in "Is computer-aided teaching an effective tool in the teaching of reading and writing in the classroom," prepared a software program which comprised of audio, educational research clips, and phonetics. The sample respondents supported the value and effectiveness of teaching done by a computer in flipped classroom.

Revised Manuscript Received on December 24, 2019

Vairamuthu Ramkumar, Kalsalingam Academy of Research and Education, Krishnankoil, Srivilliputtur, India Email : ramkumar.v@klu.ac.in

Ramkumar Vani, Theni Kammavar Sangam College of Technology, Theni, India. Email : ramkumarvaani@gmail.com

Khalafullah's article "Effectiveness of the use of e-learning and blended education in the development of the skills of the production of educational models in the students" reveals the effectiveness of e-learning and Blended Learning which enhances the respondents' skills to produce the educational models.

Kinsara's article focuses on the investigation and the impact of a computer-based education approach on the direct and delayed achievement of students on the techniques involved in teaching while compared with the traditional methods.

\section{OBJECTIVES}

This study tries to focus on the effective uses of blended learning among the students. How far it is useful for the students in their learning process? This study aims at the following questions

1. To find out the significant differences in English language based learning style.

2. To understand the significant difference in the motivation and interest on learning English language based on their learning style.

\section{METHODOLOGY}

To achieve the above mentioned objectives 50 sample respondents were chosen from an Engineering college who are studying second year. Sampling Random method was adopted. No differentiation was made in accordance with gender, Tamil or English medium of instruction, place of domicile (rural or urban area students). The students are divided into two groups and each group consisted of 25 students. The controlled group practiced traditional classroom teaching. The experimental group has followed blended learning teaching method.

At the end of the course, a questionnaire was provided to the students. It was designed to get their basic details, their opinion about the teaching methodology, their interest in learning and how far is the course useful to enhance their vocabulary, understanding and reading skills etc.

Analysis and Discussion

After collecting the questionnaire, a deep survey was made and analyzed. For the question, How far is the course useful to enhance the Vocabulary?

Table I - Illustrates the course useful to enhance the vocabulary.

\begin{tabular}{|l|l|l|l|l|l|}
\hline $\begin{array}{l}\text { Type of } \\
\text { Learning }\end{array}$ & Poor & Fair & Good & Excellent & Total (50) \\
\hline $\begin{array}{c}\text { Traditiona } \\
\text { 1 Learning }\end{array}$ & 2 & 18 & 5 & -- & 25 \\
\hline
\end{tabular}




\begin{tabular}{|l|l|l|l|l|l|}
\hline $\begin{array}{l}\text { Blended } \\
\text { Learning }\end{array}$ & 1 & 2 & 12 & 10 & 25 \\
\hline
\end{tabular}

From the table I, and figure 1, it is clear that traditional learning does not enhance the student's vocabulary. At the same time blended learning helps the students to enrich their vocabulary.

In the controlled group, students have to follow their teachers. Most of the students hesitate to clarify their doubts amidst other students. They are not ready to ask the meaning of some difficult words. The average students always think, "what do others think if ask a question wrongly?" But it is not same in the experimental group.

With the help of technology they have their own space in the learning process. Without hesitation, they can interact with their teachers. The assistance of computers enables them to enrich their vocabulary. While browsing, they come across many new words and know about those words now and then with the help of internet. The technological tools are attractive than the tradition tests.

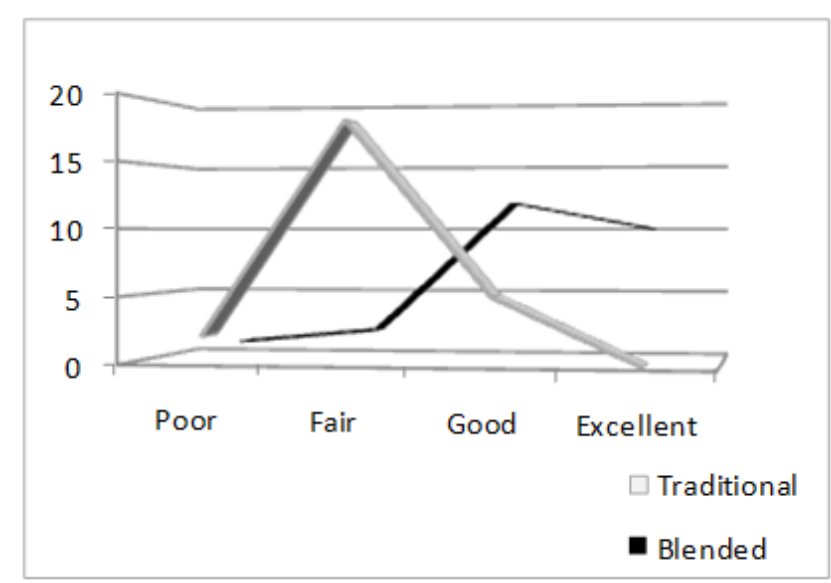

Fig 1

Table II - Are you satisfied with the Learning Environment?

\begin{tabular}{|l|l|l|l|l|l|}
\hline $\begin{array}{l}\text { Type of } \\
\text { Learning }\end{array}$ & Poor & Fair & Good & Excellent & $\begin{array}{l}\text { Total } \\
(50)\end{array}$ \\
\hline $\begin{array}{l}\text { Traditiona } \\
\text { 1 Learning }\end{array}$ & 8 & 12 & 5 & -- & 25 \\
\hline $\begin{array}{l}\text { Blended } \\
\text { Learning }\end{array}$ & -- & 8 & 10 & 7 & 25 \\
\hline
\end{tabular}

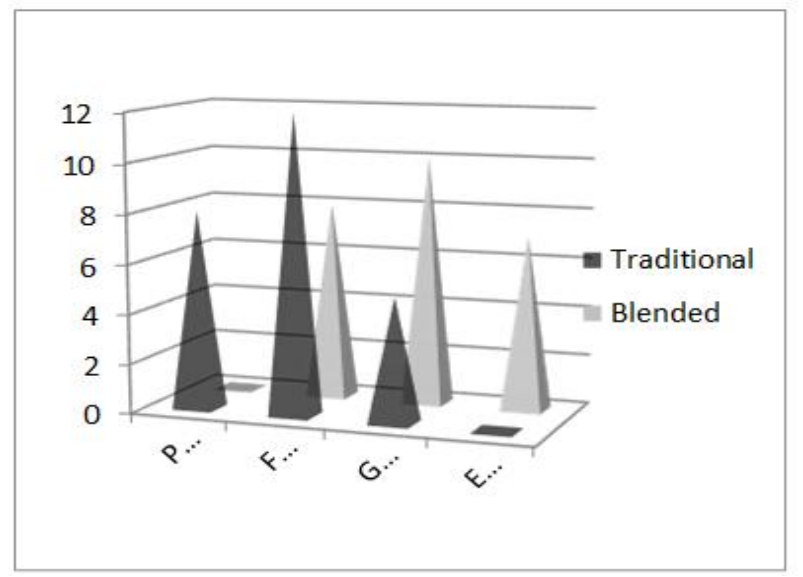

Fig 2

The table II and figure 2 depict that the students are satisfied with blended learning. Students are eagerly waiting for the opportunity to enhance their learning skills. Blended learning helps them to learn freely. In Blended learning environment 17 students have responded for good and excellent but in traditional classroom only 5 have responded. This clearly shows the students interest in technology based learning. The computers assist them to clarify their doubts. The advantages of the computerized programs lead to the better performance of the students in the experimental group. The students visualize the resources. These features prevail over the books and traditional board teaching. The students are bored with the conventional methods. This has been shown by the responses given by the controlled group.

Table III - To what extent the students are able to convert the classroom lectures?

\begin{tabular}{|l|l|l|l|l|l|}
\hline $\begin{array}{l}\text { Type of } \\
\text { Learning }\end{array}$ & Poor & Fair & Good & Excellent & $\begin{array}{l}\text { Total } \\
(50)\end{array}$ \\
\hline $\begin{array}{l}\text { Traditional } \\
\text { Learning }\end{array}$ & 2 & 18 & 5 & -- & 25 \\
\hline $\begin{array}{l}\text { Blended } \\
\text { Learning }\end{array}$ & 1 & 2 & 12 & 10 & 25 \\
\hline
\end{tabular}

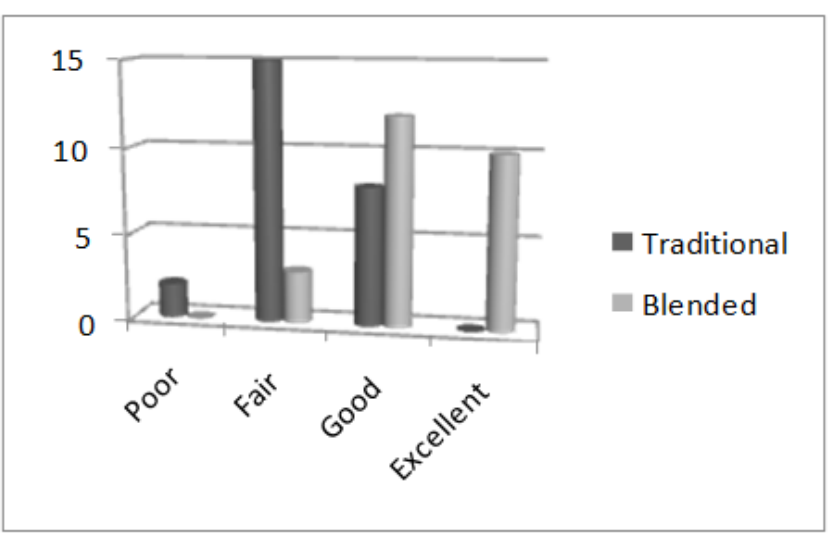

Fig 3

From the table III and figure -3 , it is understandable that blended learning method enable the students to be expressive. The experimental group students have the ability to infer a correlation between the abstract concepts and their environment. They are encouraged to oversee their learning initiatives when they are exposed to the visual settings.

The sample respondents are able to understand the topics and come out with answers in the oral as well as written communication. This is not in the case of the controlled group students. They always rely on their teachers for everything. The picture visualizes the fact clearly.

\section{Conclusion}

The assistance of Internet and Visual Aids promote the students participation in the learning process. So visual connection should be enabled to the concepts handled in the class rooms to increase the students' responses. The facts and tasks given by the computer ignite the students' internal motivation as they are liked by the students.

Published By:

Blue Eyes Intelligence Engineering

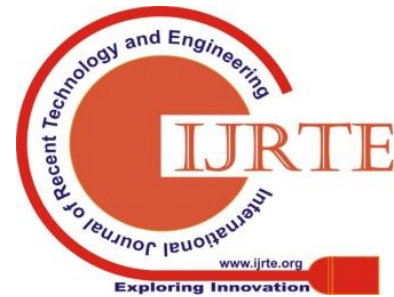


It's a known fact that Internal motivation is stronger the external motivation and long lasting too. At the same time, the existing online materials are not suitable to all the students it should be taken into consideration on students capability. Analyze their learning levels. Then choose the apt modules for your students. Switching from the traditional face to face teaching and incorporating blended learning may take some time. Slow starting provides the learners time to adapt gradually to the blended learning methods.

\section{RECOMMENDATIONS}

This study recommends the following based on the results:

1. The students' concert was good while Blended learning was adopted in addition to traditional methods.

2. Similar studies have to ensure the effects of Blended learning on other variables such as Arts and Science students for Listening, Speaking, Reading, and Writing skills.

\section{REFERENCES}

1. Abadi,M "E-learning and traditional education: what is the difference?," Al Maerefah, vol. 36, (91), 2002, pp. 18-23.

2. Khalafullah, $\mathbf{M}$ "Effectiveness of the use of e-learning and blended education in the development of the skills of the production of educational models in the students of the Department of Educational Technology, Faculty of Education, Al-Azhar University," Journal of the Faculty of Education, 2010.

3. Kinsara. H, "E-Impact of the Preventive Education Strategy Using Computer on the Direct And Deferred Achievement of the Students of the Curriculum of Educational Techniques Compared to the Individual and Traditional Method," Um Al Qura University of Educational and Psychological Sciences, Umm Al Qura University, Makkah Al Mukarramah, Saudi Arabia, 2009.

4. Keller,J. M "First principles of motivation to learn and e-learning," Distance Education, vol. 29, (2), 2008.

5. Klimova,B "Evaluation of the blended learning approach in the course of business English-A case study," Emerging Technologies for Education, LNCS 10676, pp. 326-335.

6. Nuno, J. A“Is computer-assisted instruction an effective tool in the reading-writing classroom?," Dissertation Abstract International, vol.43, (5), 2005

\section{AUTHORS PROFILE}

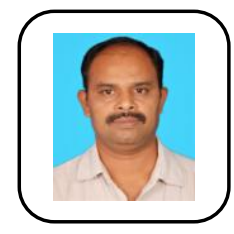

Dr. E. V. Ramkumar, born in 1975, has research knowledge in English Language Teaching. He was awarded $\mathrm{PhD}$ in the year 2014 and M. Phil in English and Comparative Literature by 2002, and Master's Degree English by 1998 . He has 13 years of teaching and research experience and works as Associate Professor in the Department of English, School of Liberal Arts and Special Education in the Kalasalingam Academy of Research and Education, Tamilnadu, India. He has more than 5 publications in Refereed journals. He is a life member of ELT@I

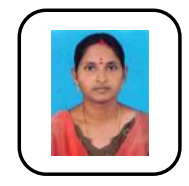

Mrs. R. Vani, born in 1977 , has research knowledge in English Language Teaching and Diaspora studies. She was awarded M. Phil in English and Comparative Literature by 2002, and Master's Degree English by 1999. She has 13 years of teaching and research experience and works as Assistant Professor in the Department of English, in Theni Kammavar Sangam College of Technology, Theni, Tamilnadu, India .She has more than 4 publications in Refereed journals. He is a life member of ELT@I. 